\title{
Allelopathic Interaction between a Medicinal Plant; Achillea santolina L. and two Associated Soil Algae Species
}

\author{
Salama M. El-Darier* and Abdelfattah K. Metwally \\ Botany and Microbiology Department, Faculty of Science, Alexandria University, Alexandria, Egypt
}

\begin{abstract}
Allelopathic effects of the aqueous extract of the medicinal plant; Achillea santolina on growth and distribution of two associated soil algae; Chlorella vulgaris (Chlorophyta) and Lyngbya contorta (Cyanophyta) were investigated under controlled laboratory conditions. The phytochemical analysis of $A$. santolina showed that it contains essential oils, flavonoids, glycosides, phenolic compounds, sterols, triterpenes and tannins. The algal flora inhabiting the soil away (control site) and underneath of $A$. santolina rooting zone were also identified. The results cleared a remarkable negative allelopathic effect of A. santolina aqueous extract on growth of $L$. contorta, and a detrimental positive effect on growth of $C$. vulgaris. Similarly, growth of $C$. vulgaris was significantly $(P \leq 0.01)$ inhibited especially at the higher extract concentrations. Growth promotion $(p \leq 0.05)$ of $L$. contorta was attained at high concentrations. The stress effect on protein profile and antioxidant activity was more prominent in $C$. vulgaris than $L$. contorta. The allelopathic effect of A. santolina extract may be due to the high concentrations of both flavonoids and total phenolics (7.98 and $29.72 \mathrm{mg} / \mathrm{g}$, respectively).

Keywords: Allelopathy, Achillea santolina, Chlorella vulgaris, Lyngbya contorta, Growth, Active constituents.
\end{abstract}

\section{INTRODUCTION}

Allelopathy is a prevalent natural phenomenon in terrestrial and aquatic ecosystems. It is now widely accepted that plants, macrophytes and various microorganisms can produce and release chemicals into the surrounding environment (Gross, 2003). The modes of release for allelochemicals are volatilization, residue decay, leaching or root exudation (Bais et al., 2003). The phenomenon has been extensively studied in terrestrial habitats and harmful effects of plants on other plants or crops are quite well known. The involved allelopathic compounds (allelochemicals) have been explored as natural substitutes of pesticides for pest control (El-Darier et al., 2018).

Allelochemicals interaction is possible in aquatic as well as terrestrial environments. The benefit of producing the allelochemicals is a reduction of comp- etetion in the immediate environment. However, there are some categorical differences between allelepathy in an aqueous medium and allelopathy on a terrestrial substrate (Mulderij et al., 2007). Importantly, the continuous movement of water disperses any water soluble allelochemicals from its point of release, thus diluting it rapidly (lewis, 1986). The overall effects of the donor plant on growth of the target species were species - specific and inhibitory, stimulatory or none depend on the target species. Most of the allelopathic effects were conducted in aquatic environments, but few works have been done on the allelopathic effects between the terrestrial plants and the accompanied soil algae (Yang et al., 2012). Allelochemicals are considered promising source of algaecides to control algal blooms (Hong et al., 2009). However, the role played by allelochemicals is mostly interpreted now in an ecological way, usually in some means of plant defense against other plants, pests or diseases.

The presence of oxygen in the cellular environment is an oxidative threat to cellular structures and processes of the organisms. Reactive oxygen species (ROS) are formed by the partial reduction of oxygen and can react with certain biomolecules, altering or inactiveating the biochemical activities. Algae minimize free radical damage by enhanced antioxidant defense (Chokshi et al., 2017; Kazir et al., 2019).

Vegetative storage proteins (VSPs) are proteins that accumulate in vegetative tissues such as leaves, stems and tubers, depending on the plant species (El-Khawas and Shehata, 2005). The vegetative storage protein analysis function apparently to sequester temporarily excess amino acids that can later be released for recycle (Staswick, 1997), shoot regrowth and spring growth for perennials and trees (Bouchart et al., 1998). Sodium Dodecyl Sulphate Polyacrylamide Gel Electrophoresis (SDS-PAGE) is most economical simple and extensively used biochemical technique for determination of molecular mass of protein subunits (Vishwanath et al., 2011).

The vital objective of the present work was focused on the allelopathic effects of water extract of Achillea santolina (donor species) on growth of two selected members of soil algae (recipient species); Chlorella vulgaris (Chlorophyta) and Lyngbya contorta (Cyanophyta). The two species were chosen on the basis of their flourishing in all the year round in two different ecological sites.

\section{MATERIALS AND METHODS}

\section{Plant Materials}

(A) Collection and manipulation of Achillea santolina

The present study was conducted in the laboratory of Botany and Microbiology Department, Faculty of Science, Alexandria University, Alexandria, Egypt. Samples of the whole plant of A. santolina have been collected from different locations at the western Mediterranean coastal region of Egypt. The collected materials were washed with tap then with distilled water, dried in shade, then ground in a Wiley Mill to coarse uniform texture and stored in a desiccator until use.

\footnotetext{
*Corresponding author e-mail: salama_eldarier@yahoo.com
} 
Twenty grams powder of the air dried donor plant were mixed with 1 liter autoclaved distilled water, shacked for $24 \mathrm{~h}$ at $20^{\circ} \mathrm{C}$ and darkness and separated by centrifugation at 5000 r.p.m. The combined aqueous extract was evaporated to dryness. After evaporation the residue was redissolved in $100 \mathrm{ml}$ distilled water to form a stock solution (200 ppm). This was considered as the full strength concentration. Subsequently, it was kept in a refrigerator at $5^{\circ} \mathrm{C}$ until used. Series of dilutions $(25,50,75$, and $100 \%$ besides the control) were prepared from the stock solution and tested for their effects on growth and some metabolic activities of the two selected soil algae.

The presence of sterols or terpenes, carbohydrates or glycosides, tannins, flavonoids, saponins, alkaloids and coumarins was evaluated according to Harborne (1984). The essential oil was extracted from the fresh plant by hydrodistillation method using Clevenger apparatus (Odalo et al., 2005).

(B) Collection and manipulation of Chlorella vulgaris and Lyngbya contorta

Soil samples were collected from two different sites; the first was far away from the shadow of A. santolina (control site), while the second was established under the shadow of the species. The current study followed the method described by Cameron and Blank (1965) for soil algae identification. In this method soil samples were added into Petri dishes contained enrichment culture media and placed in culturing room with constant temperature and light $\left(25^{\circ} \mathrm{C}\right.$ and $\left.4000 \mathrm{lux}\right)$.

The enrichment culture medium that used for isolating the two soil algae was described by Rippka and Hard man (1993). C. vulgaris was cultured in Bold's basal medium (Bischoff and Bold, 1963) while L. contorta was cultured in MBL medium (Nichols, 1973). These two organisms were prepared as axenic cultures. Algal culture was grown in Erlenmeyer pyres -glass flasks capacity of $250 \mathrm{ml}$ containing $100 \mathrm{ml}$ culture medium to which different concentrations of $A$. santolina extract added to the culture media. The flasks were grown under controlled light and temperature culture chamber under a regime of $16 \mathrm{~h}$ light $/ 8 \mathrm{~h}$ dark and $25^{\circ} \mathrm{C}$ incubation temperature.

\section{Growth Measurements}

The growth of the investigated algae was determined couple of days by optical density using Perkin Elmer (Lambada 1) ultra violet spectrophotometer at wave length of $625 \mathrm{~nm}$. The measurements of optical density (turbidity technique) were particularly suitable for determination of growth rate according to the following equation (Levasseur et al., 1993):

$$
\left[\mathrm{K}^{\prime}\right]=\operatorname{Ln}\left(\mathrm{N}_{2} / \mathrm{N}_{1}\right) /\left(\mathrm{t}_{2}-\mathrm{t}_{1}\right)
$$

Where $\mathrm{N}_{1}$ and $\mathrm{N}_{2}=$ optical density at time $1\left(\mathrm{t}_{1}\right)$ and time $2\left(\mathrm{t}_{2}\right)$ respectively.

Inhibition percentage (IP) was calculated according to Zhen et al., (2008).

$$
\mathrm{IP}=\left[1-\left(\mathrm{N} / \mathrm{N}_{0}\right)\right] \times 100
$$

Where $\mathrm{N}_{0}$ and $\mathrm{N}$ were the optical density in the control and treated cultures, respectively.

\section{Protein electrophoresis}

Proteins were separated by $15 \%$ SDS Polyacrylamide gel electrophoresis (SDS-PAGE) according to Laemmli (1970). The percentage of polymorphism was determined according to the following equation:

Polymorphism $(\%)=[(\Sigma$ bands for sample $-\Sigma$ com-mon bands for sample) / $\Sigma$ bands of all samples] x100

\section{Total antioxidant activity}

The antioxidants capacity was performed by the reaction of antioxidants enzymes in the sample with a definite amount of exogenously provide hydrogen peroxide $\left(\mathrm{H}_{2} \mathrm{O}_{2}\right)$ as described by Koracevic et al., (2001). The antioxidants capacity measured spectrophotometrically at $505 \mathrm{~nm}$ and calculated as follows:

$$
\mathrm{Mm} / \mathrm{L}=\mathrm{A}_{\mathrm{B}}-\mathrm{A}_{\mathrm{SA}} \times 3.33
$$

$\mathrm{A}_{\mathrm{B}}=$ absorbance of blank

$\mathrm{A}_{\mathrm{SA}}=$ absorbance of sample

All the data were subjected, where suitable, to standard one-way analysis of variance (ANOVA) ( $p \leq$ 0.05 was considered as significant) according to COSTAT 2.00 statistical analysis software supplied by CoHort Software Company (Zar, 1984); pairwise comparisons of means were performed using Least Significant Differences (LSD) at 0.05 probability level.

\section{RESULTS}

\section{Phytochemical analysis of Achillea santolina}

The phytochemical screening of $A$. santolina revealed that it contains essential oils, flavonoids, glycolsides, phenolic compounds, sterols/triterpenes, and tannins (Table 1). While, alkaloids, coumarins and saponins were absent. Data in Table 2 clearly demonstrated that the values of total flavonoids, total phenollics, and essential oils were $7.985 \mathrm{mg} / \mathrm{g}, 29.725 \mathrm{mg} / \mathrm{g}$ $0.65 \%$, respectively.

Table (1): Qualitative evaluation of some active constituents in Achillea santolina.

\begin{tabular}{lc}
\hline \hline Component & Currency \\
\hline Alkaloids and /or nitrogenous bases & - \\
Coumarins & - \\
Essential oils & ++ \\
Flavonoids & +++ \\
Glycosides & ++ \\
Phenolic compounds & ++ \\
Saponins & - \\
Sterols and / or triterpenes & ++ \\
Tannins & + \\
\hline \hline
\end{tabular}

+, low concentration; ++, moderate concentration; +++, high concentration; -, Absent 
Table (2): Quantitative content of total flavonoids, phenolics and essential oils in Achillea santolina.

\begin{tabular}{lccc}
\hline \hline Donor species & $\begin{array}{c}\text { Total flavonoids } \\
(\mathbf{m g} / \mathbf{g})\end{array}$ & $\begin{array}{c}\text { Total phenolic } \\
(\mathbf{m g} / \mathbf{g})\end{array}$ & Essential oil (\%) \\
\hline Achillea santolina & 7.985 & 29.725 & 0.65 \\
\hline \hline
\end{tabular}

\section{Description of soil algae}

The algae grown in soils at the control site and underneath A. santolina were identified and represented in Table 3. The algal groups detected are related to Cyanophyta, Chlorophyta and Bacillariophyta. The total number of green algal species was higher than both the blue green algae and diatoms. Eleven species were isolated from the two collected soil samples. These species included four genera of blue green algae, five genera of green algae and two genera of diatoms. The eleven collected algal species revealed that the green algae were absent underneath $A$. santolina, while blue greens and diatoms were present in both sites.

Table (3): Algal identification at control site compared to those grown underneath Achillea santolina site.

\begin{tabular}{lcc}
\hline \hline \multicolumn{1}{c}{ Species of algae } & Soil at control Site & Soil Underneath A. santolina plant \\
\hline Cyanophyta & + & + \\
Lyngbya contorta & + & + \\
Anabaena circinalis & + & + \\
Phormidium fragile & + & + \\
Oscillatoria sancata & & \\
Chlorophyta & + & - \\
Chlamydomonas reinhardtii & + & - \\
Chlorococcum humicola & + & - \\
Chlorella vulgaris & + & - \\
Scenedesmus linearis & + & - \\
Oocystis borgei & & + \\
Bacillariophyta & + & + \\
Navicula viridula & + & \\
Nitzschia palea & + & \\
\hline \hline
\end{tabular}

Consequently, the two algal species selected were C. vulgaris (absent in the soils from the shade of A. santolina plant) and $L$. contorta (isolated from the two types of soil).

Effect of Achillea santolina aqueous extract on optical density and growth rate of Chlorella vulgaris and Lyngbya contorta

(A) Chlorella vulgaris

Data concerning the effect of A. santolina extract on optical density and growth rate of $\mathrm{C}$. vulgaris cultured for 14 days were recorded in Figure 1. These data revealed that the mean growth rate at control and at the

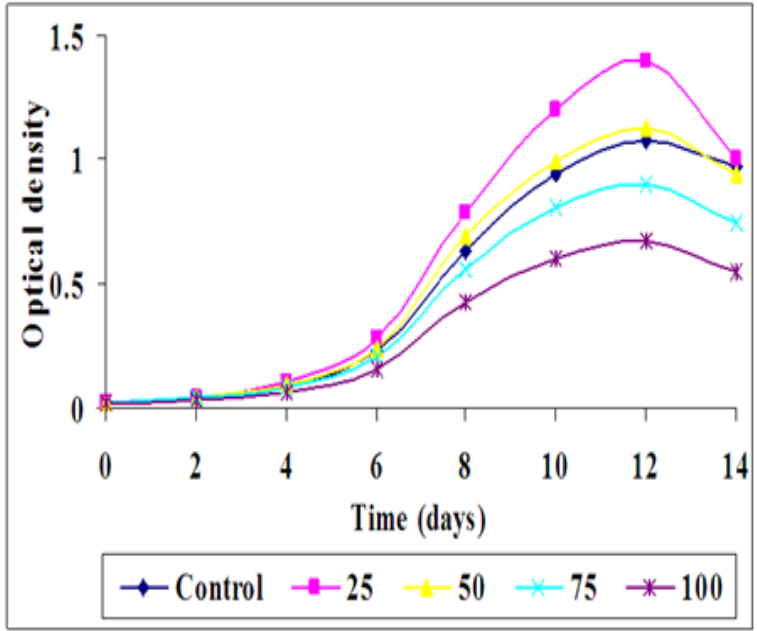

treated cultures reached their maximum value at the 8th day of culturing. However, by increasing the concentration of the extracts values of growth increased gradually till the 12th day of culturing, then decreased gradually till the end of the experiment. In addition, the more the concentration of the extract, the less are the values of growth until the end of the experiment (14days of culturing).

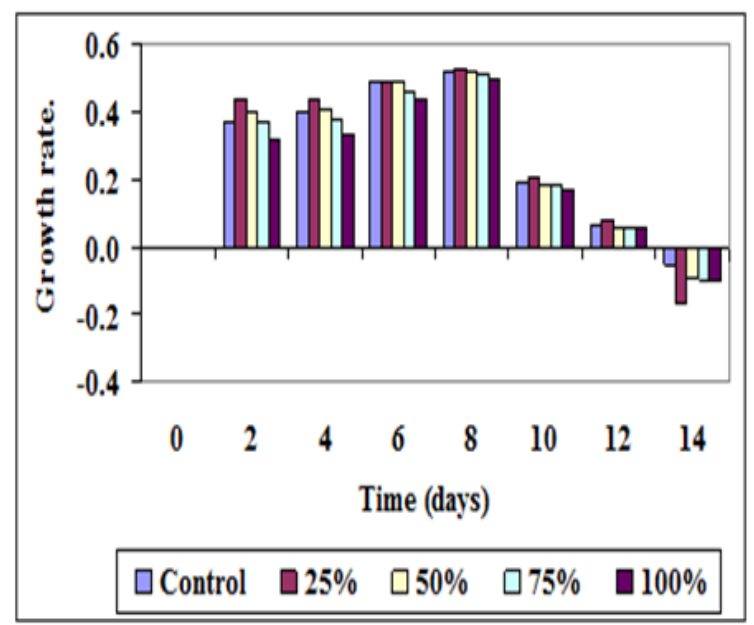

Figure (1): Optical density and the mean growth rate of Chlorella vulgaris cultured for 14 days under the effect of different concentrations of Achilleasantolina aqueous extract. 


\section{(B) Lyngbya contorta}

Data concerning the effect of $A$. santolina extract on growth of $L$. contorta (optical density) were recorded in figure 2. It is clear from these data that growth rate and mean growth rate of the organism reached its maximum value at the $8^{\text {th }}$ day of culturing. At $100 \%$ extract concentration, the inhibition percentage (IP) in growth rate of $C$. vulgaris at the $10^{\text {th }}$ day reached $61.2 \%$ compared to the control. Notably, at the $14^{\text {th }}$ day of culturing the IP was decreased to $44.2 \%$. On the other hand, maximum IP $(88.8 \%)$ in growth rate of $L$. contorta was attained at $2^{\text {nd }}$ day of culturing. A percent of about $35.7 \%$ increase at the $8^{\text {th }}$ day of culturing was achieved relative to control. However, at the 14th day the percent of decrease reached $16 \%$ at the same concentration (Figure 3 ).

Effect of A. santolina on protein pattern of selected soil alga

Different concentrations of $A$. santolina-aquaous extract showed a significant effect on protein pattern of two selected members of soil algae, Chlorella vulgaris and Lyngbya contorta, in which protein pattern were very

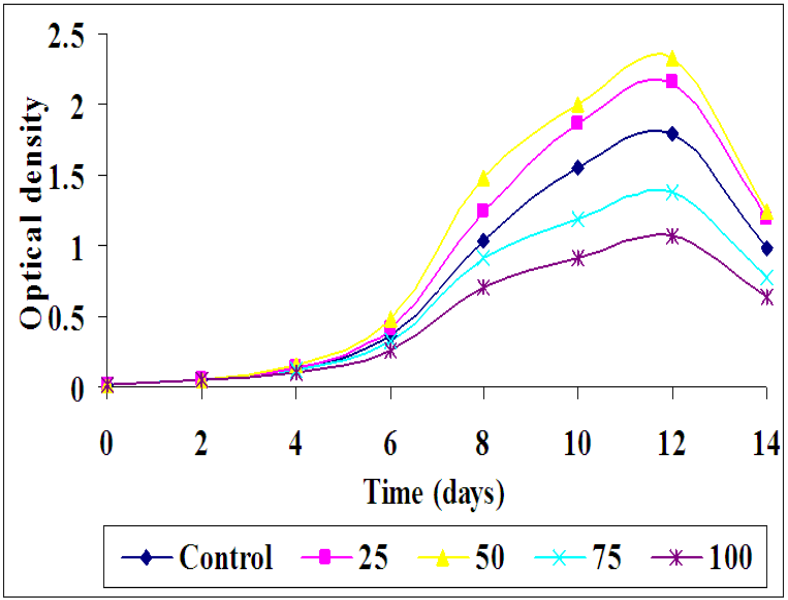

very difference between control and grown cells (Plate 1). Increasing the concentration of aqueous extract of $A$. santolina was dramatically affect the pattern of protein profile for Chlorella vulgaris and Lyngbya contorta (Plate 1, a and b, respectively).

\section{DISCUSSION}

Allelopathy is widely understood as the inhibitory or stimulatory effects of one plant; donor or test on another plant; target or recipient due to the release of biologically active biomolecules named allelechemicals (Chon and Nelson, 2010). The core objective of the present work was focused on the effect of different concentrations of water extract of A. santolina (donor species) on growth of two selected members of soil algae namely; Chlorella vulgaris and Lyngbya contorta (target species). However, few works have been carried out on the allelopathic effects between higher plants and soil microalgae (Yang et al., 2012).

Field observations as well as isolation and character-

Figure (2): Optical density and mean growth rate of Lyngbya contorta cultured for 14 days under the effect of different concentrations of Achillea santolina extract.

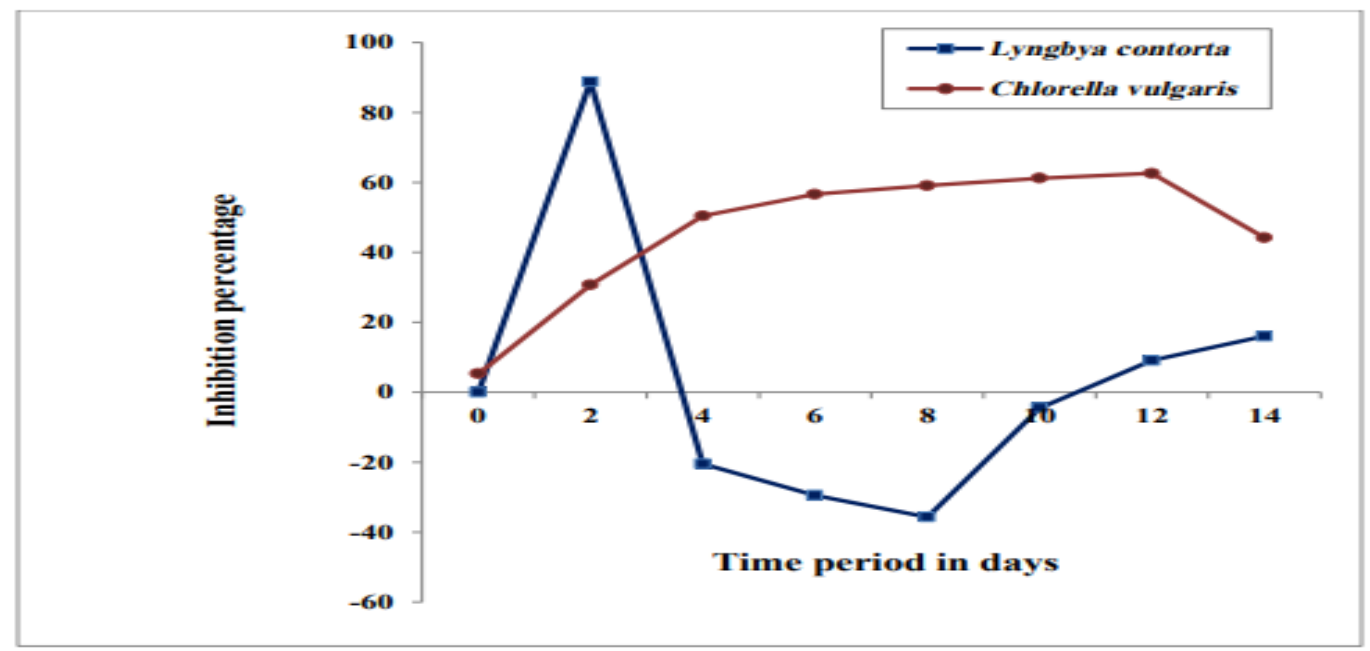

Figure (3): Inhibition percentage in growth of Chlorella vulgaris and Lyngbya contorta cultured for 14 days under the effect of $100 \%$ concentration of Achillea santolina extract. 
ization of algal species indicated that members of Chlorophyta were dominant only in soils far away from $A$. santolina and nearly absent below shadow of $A$. santolina. This fact was supported by the idea of Morales-Flores et al., (2007). They reported that the photosynthetic machinery of chloroplasts is a preferred target for allelochemicals. Contrarily, the members of the blue green algae grew normally below or away from $A$. santolina. The phytochemical screening of $A$. santolina indicated that it contains essential oils, flavonoids, glycosides, phenolic, sterols/triterpenes, and tannins compounds. In addition, total flavonoids, total phenolic, and essential oil content attained values of about $7.985 \mathrm{mg} / \mathrm{g}, 29.725 \mathrm{mg} / \mathrm{g}$ and $0.65 \%$, respecttively. This may support the idea that the inhibitory effect of Achillea santolina extract probably due to the presence of high concentrations of these allelechemicals. This coincides with those obtained by different studies of Sasikumar et al., (2002) and El-Darier and El-Bakkosh (2011). Higher concentrations of allelochemicals influenced growth and different physiological processes during the period of plant growth (Olofsdotter, 1998).

According to the present study, the considerable inhibition of algal growth parameters may be due to the inhibitory effect of allelochemicals, such as, phenolic, terpenoids and flavonoids, which could affect growth directly or by altering the mobilization of storage compounds during growth. This suggestion has been confirmed by using different concentrations of $A$. santolina extract and its effect on the total antioxidant activity in Chlorella vulgaris and Lyngbya contorta. The data showed that Chlorella vulgaris displayed a significant decrease in total antioxidant activity, meanwhile, Lyngbya contortawas was not affected (Table 4).
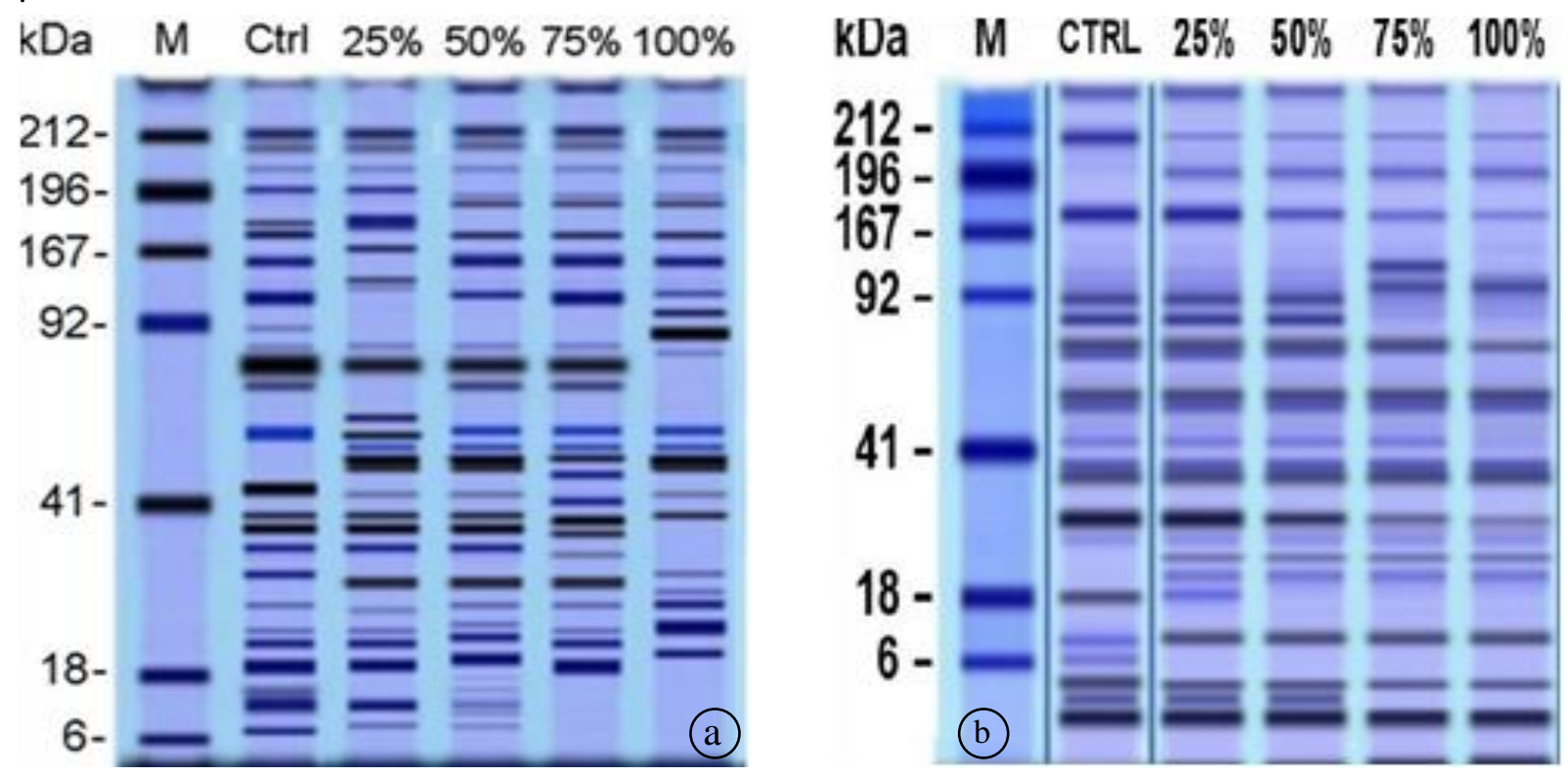

Plate 1: Patten of protein profile for Chlorella vulgaris (a) and Lyngbya contorta (b) cells cultured for 10 days under the effect of different concentrations of Achillea santolina aqueous extract.

Table (4): Effect of different concentrations of Achillea santolina extract on the total antioxidant activity in Chlorella vulgaris and Lyngbya contorta.

\begin{tabular}{lccccc}
\hline \hline \multirow{2}{*}{ Algal species } & \multirow{2}{*}{ Control } & \multicolumn{4}{c}{ Extract concentration (\%) } \\
\cline { 3 - 6 } & & $\mathbf{2 5}$ & $\mathbf{5 0}$ & $\mathbf{7 5}$ & $\mathbf{1 0 0}$ \\
\hline Chlorella vulgaris & 9.4 & 6.5 & 4.5 & 2.5 & 2.4 \\
Lyngbya contorta & 7.2 & 7.3 & 7.6 & 7.7 & 7.8 \\
\hline \hline
\end{tabular}

Likewise, mobilization; a process which usually takes place rapidly during early stages of algal growth seems to be delayed or decreased under allelopathy stress conditions (Muscolo et al., 2001; Gniazdowska and Bogatek, 2005). Data proved that in case of $C$. vulgaris the more the concentration of the extract, the less is the values of growth. These results coincided with those obtained by Ahrabi et al., (2011). Similarly, Li and Hu
(2004) observed that extracts from some macrophytes inhibited the growth of Chlorella pyrenoidosa. Conversely, in case of $L$. contorta, the growth increased by increasing the concentration of the extract.This may explain why $L$. contorta was found in soil at the shadow of $A$. santolina where it flourished well and the growth increased by increasing the concentration of the extract. Furthermore, Ferrier et al., (2005) found that 
the aqueous extract of barley straw liquor significantly increased growth of Oscillatoria lutea and Navicula sp. While Ulothrix fimbriata, Scenedesmus quadricauda and Chlorella vulgaris showed no significant difference from controls. Moradi and Ismail (2007) and Ghezelbash et al., (2008) reported that reduction in growth rate is due to the decrease in the photosynthetic rate.

The destructive effect of $A$. santolina extracts on protein profile was more prominent in $C$. vulgaris than in $L$. contorta which coincided with results obtained by Ahmed (2010) and El Taher (2012). Therefore, changes in protein composition of these organisms may also be involved in adaptation processes (Hagmann et al., 1990). Protein synthesis in the stress adaptation mechanism in the two studied algae revealed the occurrence of species stressed proteins for a particular environmental stress factors (A. santolina extract). Maha (2003) reported that, Nostoc linckia cultured under stress conditions showed the appearance of two new bands compared with control. In addition, Ahmed (2010) stated that, the tolerance of an organism to stress conditions could be achieved through synthesis or accumulation of new proteins. These results are nearly in harmony with the results of the present study. A. santolina extract stress may trigger the expression of the antioxidative defense systems. This is evident from the fact that, total antioxidants including nonenzymatic and enzymatic antioxidants, showed in general an increase with increasing stress indicating a cellular capacity to overcome the stress. This conclusion can be substantiated if the degree of stress is not so high to concentration limit that may cause damage and death of the organism (Hamid and Sibi, 2018; Kazir et al., 2019). The same conclusion was also observed for $C$. vulgaris where the total antioxidant activity began to decrease at the higher concentration of $A$. santolina extracts.

Finally, we concluded that Chlorophyta species were dominated only in soils of the control site of $A$. santolina, while Cyanophyta and Diatoms species were identified in both types of soil. $C$. vulgaris and $L$. contorta were chosen because both organisms flourish all the year in their sites. In conclusion, future studies on A. santolina interactions with soil algae and microorganisms must be focus on other algal groups in order to understand the effect of allelochemicals from higher plants on soil organisms. More experiments however, are needed to prove the general existence and importance of allelopathy in these ecosystems under different environmental and geographical conditions.

\section{REFERENCES}

Ahmed E. A. M. (2010). Impact of Tributyltin (TBT) on metabolism of some marine algae. Ph.D. Thesis. Faculty of sci, Alazhar University. Egypt.

Ahrabi, F., Enteshari,S.H., Moradshahi, A. (2011). Allelopathic potential of para-hydroxybenzoic acid a coumarin on canola: Talaieh cultivar. Med. Plant Res., 5(20): 5104-5109.
Bais, H.P.; Vepachedu, R.; Gilroy, S.; Callaway, R.M. and Vivanco, J.M. (2003). Allelopathy and exotic plant invasion: from molecules and genes to species interactions. Science, 301(5638): 1377-1380.

Bischoff, H.W. and Bold, H.C. (1963). Some soil algae from enchanted rock and related algal species. Texas. University. Phycological Studies. Univ. Texas. Publ. N. 6318:32-36.

Bouchart, V.; Macduff, J.; Ourry, A.; Svenning, M.; Gay, A.; Simon, J. and Boucaud, J. (1998). Seasonal fluctuations of vegetative storage proteins and starch concentrations in stolon's of Trifolium repens L. Physiologia Plantarum, 1: 65-74.

Cameron, R.E. and Blank, G.B. (1965). Soil studies desert microflora. X. Soil properties of samples from Chile Atacama Desert, JPL Space Programs Summary, 37-35(IV): $214-222$.

Chokshi, K., Pancha, I.; Ghosh, A. and Mishra (2017).

Nitrogen starvation-induced cellular crosstalk of ROS-scavenging antioxidants and phytohormone enhanced the biofuel potential of green microalga Acutodesmus dimorphus. Biotechnology for Biofuels, 10:60.

Chon, S. U. and Nelson, C.J. (2010). Allelopathy in Compositae plants. A review. Agron. Sustain. Dev. 30: 349-358.

El-Darier, S.M.; El-Bakkosh, A.M. (2011). Allelopathic effects of some medicinal plants harvested from different locations on germination and growth of a noxious weed, Medicago polymorpha L. The $6^{\text {th }}$ world Congress on Allelopathy, 15-19 December, Guangzhou, China.

El-Darier, S.M.; El-Kenany, E.T.; Abdellatif, A.A. and Abdel Hady, E.F. (2018). Allelopathic prospective of Retama raetam L. against the noxious weed Phalaris minor Retz. growing in Triticum aestivum L. fields. Rendiconti Lincei. Scienze Fisiche e Naturali 29:155-163.

El-Khawas, S. A. and Shehata, M. M. (2005). The Allelopathic potentialities of Acacia nilotica and Eucalyptus rostrata on monocot (Zea mays L.) and dicot (Phaseolus vulgaris L.) plants. Biotechnology, 1: 23-34.

El Taher A. M. (2012). Copper and zinc toxicity in Chlorella vulgaris: Response of growth; some metabolic and antioxidants activity. M.Sc. Thesis. Fac. of Sci. Alex. Univ. Egypt.

Ferrier, M.D.; Butler, B.R.;Terlizzi, D.E. and Lacouture R.V. (2005). The effects of barley straw (Hordeum vulgare) on the growth of freshwater algae. Bioresour. Technol., 96(16): 1788-1795.

Ghezelbash, F.;Farboodnia, T.;Heidari, R. andAgh, N. (2008). Biochemical effects of different salinities and luminance on green microalgae Tetraselmis chuii. Res. J. Biol. Sci., 3(2): 217- 221.

Gniazdowska, A. and Bogatek, R. (2005). Allelopathic interactions between plants. Multi-site act ion of allelochemicals. Acta Physiol. Plantarum, 27(3): 395-407.

Gross, E.M. (2003). Allelopathy in aquatic autotrophs. Crit Rev Plant Sci, 22: 313-339. 
Hagmann M.; Wolfel L. and Krl Ulger B. (1990). Alternation of protein synthesis in the cyanobacterium Synechocystis sp. PCC 6803 after salt shock. J. Gen. Microbiol. 136: 1393-1399.

Hamid, S. and Sibi, G. (2018). Antioxidant system response in green microalga Chlorococcopsis minuta against nutrient stress in growth media. Asian Journal of Biological Sciences, 11 (4): 210216.

Harborne, J. B. (1984). Phytochemical Methods: A Guide to Modern Technique of Plant Analysis. Chapman and Hall, London.

Hong, Y.; Hu, H.Y.; Xie, X., Sakoda, A.; Sagehashi, M. and Li, F.M. (2009). Gramine-Induced Growth Inhibition, Oxidative Damage and Antioxidant Responses in Freshwater Cyanobacterium Microcystis Aeruginosa. Aquat. Toxico., 91(3): 262-269.

Kazir, M.; Abuhassira, Y.; Robin, A.; Nahor, O.; Luo, J.; Israel A.; Golberg, A.; Livney, Y. (2019). Extraction of proteins from two marine macroalgae, Ulva sp. and Gracilaria sp. for food application and evaluating digestibility, amino acid composition and antioxidant properties of the protein concentrates.

Koracevic, D.; Koracevic G.; Djordjevic V.; Andrejevic S. and Cosic V. (2001). Method for the measurement of antioxidant activity in human fluids. J. Clin. Pathol. 54: 356-361.

Laemmli, U.K. (1970). Cleavage of structural proteins during the assembly of the head of bacteriophage T4. Nature 227: 680-685.

Levasseur, M.; Thompson, P. A. and Harrison, P. J. (1993). Physiological acclimation of marine phytopankton to different nitrogen sources. J.Phycol., 29: 587-595.

Lewis, W.M. (1986). Evolutionary interpretation of allelochemical interactions in phytoplanktonic algae, Am. Nut., 127(2): 184-194.

Li, F.M. and Hu, H.Y. (2004). Allelopathy and inhibitory effect of extracts from macrophytes on algae growth. China Water Wastew., 20: 18-21.

Makled M. M. F. (2003). Influence of salinity stress on growth and some metabolic activities of Anabaena subcylindrica and Nostoc linckia. M. Sc. Thesis. Bot. Dept. Fac. of Sci. Tanta University, Egypt.

Moradi, F. and Ismail, A.M. (2007). Responses of Photosynthesis, chlorophyll fluorescence and ROSscavenging systems to salt stress during seedling and reproductive stages in rice. Ann. Botany. 99: 1161-1173.

Morales-Flores, F.; Aguilar, M.I.; King-Díaz, B.; de Santiago-Gómez, J.R. and Lotina-Hennsen, B. (2007). Natural diterpenes from Croton ciliatoglandulifer as photosystem II and photosystem I inhibitors in spinach chloroplasts. Photosynth. Res., 91(1): 71-80.

Mulderij, G.; van Nes, E.H. and van Donk, E. (2007). Macrophyte-phytoplankton interactions: the relative importance of allelopathy versus other factors. Ecol Model 204: 85-92.

Muscolo, A.; Panuccio, M.R. and Sidari, M. (2001). The effect of phenols on respiratory enzymes in seed germination. Respiratory enzyme activities during germination of Pinus laricio seeds treated with phenols extracted from different forest soils. Plant Growth Regul., 35(1): 31-35.

Nichols, H.W. (1973). Growth media freshwater. In:"Handbook of Phycological Methods: Culturemethods and growth measurements. (Stein JR.Ed.)",Camb. Univ. Press. (R. R. L. Guillard, personal communication). Cambridge Univ. Press, London, pp. 7-24.

Odalo, J.O.; Omolo, M.O.;Malebo, H.;Angira, J.;Njeru, P.M.; Ndiege, I.O.and Hassanali, A. (2005). Repellency of essential oils of some plants frKenyan coast against Anopheles gambiae. Acta Trop., 95(3): 210-218.

Olofsdotter, M. (1998). Allelopathy in Rice - a tool for sustainable weed management. In: Conference on biodiversity and development, 21st October 1998, Copenhagen, Denmark, pp. 94.

Rippka, R. and Herdmann, M. (1993). Pasteur culture colle ction of cyanobacterial strains in axenic culture. Vol. 1 Catalogue of Strains. Institut. Pasteur, Paris, France, pp. 103.

Sasikumar, K.;Vijayalakshmi, C. and Parthiban, K.T. (2002). Allelopathic effects of Eucalyptus on black gram (Phaseolus mungo L.). Allelopath. J., 9: 205 214.

Staswick, P. (1997). The occurrence and gene expression of vegetative storage proteins and a Rubisco complex protein in several perennial soybean species. Journal of Experimental Botany, 317: 2031-2036.

Vishwanath, K.; Prasanna, K. P.; Pallvi, H.M.; Rajendra, P. S.; Ramegowda, D. P. and Ananthararayanan, T. V. (2011). Identification of tomato (Lycopersicon esculentum) varieties through total soluble seed proteins. Research Journal of Agricultural Sciences, 1: 08-12.

Yang, X.; Deng, S.; De Philippis, R.; Chen, L.; Hu, C. and Zhang, W. (2012). Chemical composition of volatile oil from Artemisia ordosica and its allelopathic effects on desert soil microalgae, Palmellococcus miniatus. Plant Physiol. Biochem., 51: 153-158.

Zar J.H. (1984). Biostatistical analysis, 2nd edn. Prentice-Hall International Inc, Englewood Cliffs.

Zhen, A.N.; Zhenyu, W.A.N.; Fengmin, L.I.; Zhijia, T.I.A. and Hongying, H.U. (2008). Allelopathic inhibition on red tide microalgae Skeletonema costatum by five macroalgal extracts Front. Environmental Science and Engineering, China, 2(3): 297-305. 


\section{التداخل الأليلوباثي بين التبات الطبي؛ البعيثران واثثين من أنواع الطحالب الموجودة بالتربة سلامه الضرير وعبدالفتاح متولي \\ قسم النبات و علم الاحياء الدقيقه, كليه العلوم, جامعه الاسكندريه، مصر ملائر

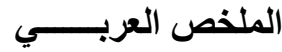

لقد تم معمليا إختبار التأثير الاليلوباتي للمستخلص المائي للنبات الطبي؛ Achillea santolin على نمو وتوزيع اثثين

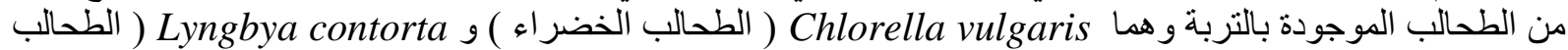

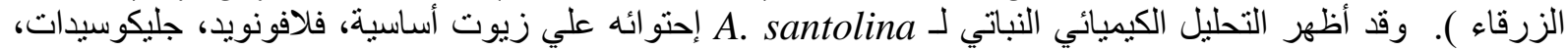

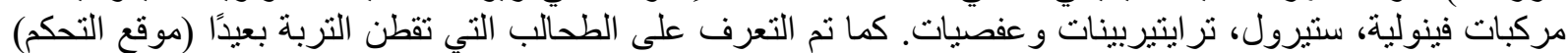

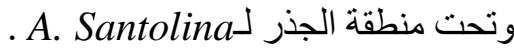

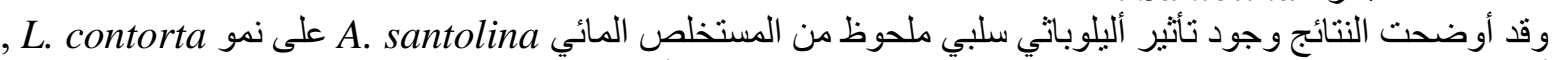

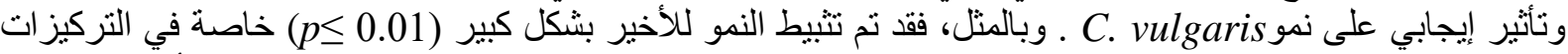

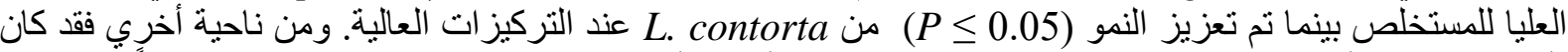

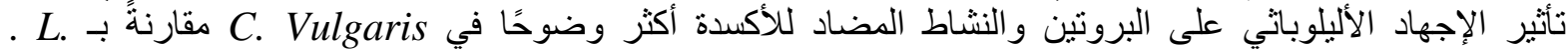
وقد لخصت النتائج إلي أن التأثير الأليلوباني لمستخلص Aontorta الفلافونويد و الفينو لات الكلية (7.98 و 29.72 ملغم / جم ، على التوالئيلئ. 